\title{
GH therapy and cancer risk in hypopituitarism: what we know from human studies
}

\author{
Sandra Pekic and Vera Popovic \\ Faculty of Medicine, University of Belgrade and Clinic for Endocrinology, Diabetes and Metabolic Diseases, University Clinical Center Belgrade, \\ Dr Subotica 13, 11000 Belgrade, Serbia \\ (Correspondence should be addressed to V Popovic; Email: popver@eunet.rs)
}

\begin{abstract}
It has been difficult to identify factors that affect the risk of cancer, but we know that people are at higher risk as they get older, or if they have a strong family history of cancer. The potential influence of environmental and behavioral factors remains poorly understood. Early population-based and casecontrol studies suggested that higher serum levels of IGF1 could be associated with increased cancer risk. Since GH therapy increases IGF1 levels, concern has been raised regarding its potential role as a cancer initiation factor. Experimental evidence and some clinical studies showed that when GH/IGF1 secretion or action was inhibited, a decreased incidence and rate of progression of cancers occurred. However, human populations comprise a garden variety of genotypes that respond differently to the same kind of exposures. Human population studies frequently reveal only very small effects to these exposures. So, are GH and cancer guilty by association? After more than 20 years, leukemia, a major safety issue initially believed associated with GH treatment in children with GH deficiency (GHD), has not been confirmed but the risk of second malignancies in patients previously treated with irradiation has been detected or confirmed through the National Cooperative Growth Study. Overall, this large study confirmed the favorable overall safety profile of $\mathrm{GH}$ therapy in children with GHD, and also highlighted specific populations at potential risk. The risk of secondary malignancy following radiotherapy is surely related to radiotherapy more than $\mathrm{GH}$ therapy that may increase growth but is less likely to start the oncogenic process. In GH-deficient adults treated with GH, observational studies (KIMS, HypoCCS) have shown that when IGF1 levels were targeted within normal age-related reference ranges, the occurrence of malignancies was not higher than in the general population.
\end{abstract}

European Journal of Endocrinology 169 R89-R97

\section{Introduction}

It has been shown by experimental studies that growth hormone (GH) and insulin-like growth factors (IGFs) have mitogenic and proliferative properties $(1,2,3,4,5,6)$. Studies in the general population suggest that highnormal serum IGF1 levels may be associated with an increased risk of malignancies $(7,8)$. The question that then begs an answer is can GH replacement therapy in GH-deficient patients increase the risk of malignancy? Epidemiological studies have reported variable results of the incidence of malignancy in GH-deficient patients treated with $\mathrm{GH}$, ranging from no increase in incidence to increased risk of malignancy in comparison with the risk in the general population $(9,10,11)$. GH replacement therapy for adults with GH deficiency (GHD) was approved in 1995. The first observational studies have suggested that $\mathrm{GH}$ replacement therapy in $\mathrm{GH}$-deficient adults is safe (12). In children, GH therapy was approved in 1985 with several hundred-thousand children receiving $\mathrm{GH}$ for growth purposes, and the overall safety remains favorable $(13,14,15)$. There were no increases in new malignancies in $\mathrm{GH}$-treated children without risk factors. However, studies in children with risk, that is, childhood cancer survivors, indicated a two- to threefold increased risk of second neoplasms in GH-treated children compared with that of non-GH-treated children $(16,17)$.

\section{Experimental data on the role that the GH/IGF system plays in cancer}

Available experimental data support the hypothesis that GH/IGF1 may influence neoplastic tissue growth. Malignant tumors have been induced in animals exposed to supraphysiological doses of $\mathrm{GH}$, while hypophysectomy appears to protect animals from carcinogen-induced neoplasms $(1,2,3,4)$. GH and IGF1 receptors are found in multiple tumors, and these hormones have potent mitogenic and antiapoptotic activities $(5,6)$. IGF1 may be involved in angiogenesis, metastasis and resistance to 
chemiotherapeutic agents $(5,6)$. The interpretation of association between circulating IGF1 levels and the risk of cancer is difficult and complex. In circulation, IGF1 is bound to IGF-binding proteins (IGFBPs) with higher affinity than to the IGF1 receptor. As a result, most of the circulating IGF1 is relatively unavailable for receptor activation. IGF1 activity at tissue level is not necessarily determined by the secretion rate of IGF 1 nor by total IGF1 concentrations (18). IGFBPs not only restrict IGF1 activity but can also enhance activity at the cellular level by enhancing delivery of IGF1 to specific tissue compartments (19). The most abundant BP in the circulation is IGFBP3. Proteases capable of cleaving IGFBP 3 are present in both the circulation and extravascular fluids. While in circulation protease inhibitors protect IGFBP3 from proteolysis, in extravascular interstitial fluids protease inhibitors are not present, which enables proteases to cleave IGFBP3, making IGF1 more available for cell receptors.

Based on experimental evidence in recent years, targeting the IGF system for anticancer therapy is a newly developing avenue (5). In general, when GH/IGF1 secretion or action is inhibited, a decreased incidence and rate of progression of cancers has been observed. Hypopituitary dwarf mice and GH receptor/ BP (GHR/BP) knockout (KO) mice showed increased longevity $(20,21)$. These animals have a lower incidence and delayed occurrence of fatal neoplastic lesions compared with their wild-type littermates. Furthermore, lit/lit mice, characterized by a nonfunctioning GHRH receptor and thus very low $\mathrm{GH}$ and IGF1 levels, show almost complete inhibition of growth of transplanted human breast cancer cells (22).

Gene knock-out and knock-in experiments in laboratory animals reveal large effects. Animals with selective KO of the hepatic IGF1 gene (and marked reduction of IGF1 levels) show marked delay in the onset and development of chemically and genetically induced mammary and colonic tumors $(23,24)$. GH transgenic mice and IGF1 transgenic mice are two different phenotypes of hypersomatotropism in whom GH/IGF systems do not have the same role in individual tumor types. IGF1 transgenic animals do not show increased incidence of bowel cancer while GH transgenics do (25). Functional IGF1 receptors on the tumor cells, such as malignant breast epithelial cells, are needed for tumor formation and progression $(26,27)$.

There are limitations to these experimental studies. Experimental animals are single genetically homogeneous rodent colonies showing large knock-out and knock-in effects. All experiments are strictly controlled under standardized conditions and without environmental stimuli (18). By contrast, human population studies examine changes in the setting of heterogeneous genotype and reveal only very small effects. Furthermore, an important distinction is the high prevalence of occult preclinical neoplasias in elderly humans; in experimental studies most animals are young and growing (27).
In summary, while the evidence of initiation of the oncogenic process may not be 'limited,' there is good evidence for tumor growth and progression in transgenic models; therefore, it is biologically plausible that the GH/IGF system is involved in oncogenesis albeit in the setting of an artificial lab environment. Many aspects of human IGF pathophysiology can only be learned from studies in humans.

\section{Circulating IGF 1 and cancer: data from the general population}

Early human population studies suggested that higher IGF1 levels could be associated with increased cancer risk $(5,7,28)$. It was observed that patients with breast cancer had higher IGF1 levels than control subjects (29). Other studies confirmed an association between serum IGF1 levels in the upper quartile and the risk of prostate, breast, and colon cancer in the general population $(30,31,32,33,34,35)$. A systematic review and metaregression analysis of epidemiological studies analyzed the association between IGF1 and IGFBP 3 with prostate, colorectal, premenopausal, and postmenopausal breast and lung cancer. High-normal IGF1 levels were associated with a twofold increased risk of prostate, colorectal, and premenopausal breast cancer but not postmenopausal breast cancer or lung cancer (7).

In a large case-control study in the UK, in which 100000 men were offered prostate-specific antigen (PSA) testing, those who had elevated PSA levels underwent prostate biopsy and measurements of IGF1, IGF2, IGFBP2, and IGFBP 3 did not find an association of IGF1 with PSA-detected prostate cancer (36). These authors concluded that reducing IGF1 might not prevent the initiation of prostate cancer but might prevent its progression. In the study of Stattin et al. (37), the patients with prostate cancer had significantly higher IGF1 levels than control subjects (mean IGF1 level: 229 vs $214 \mathrm{ng} / \mathrm{ml}$ respectively, $P=0.02$ ). The positive association between IGF1 level and prostate cancer risk was particularly strong in younger men ( $<59$ years at the time of blood collection). These data suggest that circulating IGF1 may be specifically involved in the early pathogenesis of prostate cancer. In this study, adjustment for BMI did not alter the associations of IGF1 with prostate cancer risk.

Besides IGF1, IGFBPs also have growth-regulatory effects on cells through modulation of IGF bioactivity and other mechanisms. The most frequently studied IGFBP in relation to cancer was IGFBP3. In some studies an inverse association between serum IGFBP3 levels and risk for cancers has been demonstrated $(32,33,38)$. Men in the highest quartile of IGF1 levels had a 2.6-fold higher prostate cancer risk, while men in the highest quartile of IGFBP3 levels had a $46 \%$ decreased risk compared with the lowest quartile (38). A similar result was observed for IGFBP1 in this study. The study of postmenopausal women showed an inverse association 
between IGFBP 3 and risk of breast cancer, while other IGFBPs (IGFBP1, IGFBP4, and IGFBP6) were not significantly associated with breast cancer risk (39). There are also studies that reported no association between IGFBP 3 and risk of cancer, or positive association between them $(40,41)$.

A recent meta-analysis (12 studies with 14906 participants) analyzed the association between IGF1 and mortality (42). As IGF1 levels decline with age and are dependent on sex, data had to be adjusted for at least these two variables (age and sex). This meta-analysis reported a U-shaped association between circulating IGF1 and mortality (42). Both low and high IGF1 concentrations are associated with increased mortality from cardiovascular disease and cancer. The calculated IGF1 percentile associated with the lowest mortality was the 55th percentile. The predicted risk ratio for the increase in mortality comparing the 10th and the 90th IGF1 percentile with the 50th percentile was $1.56(95 \%$ CI 1.31-1.86) and 1.29 (95\% CI 1.06-1.58) respectively (42). It has already been shown that the risk of common cancers is increased with higher IGF1 levels, but the reason for the observed association between cancer mortality and low IGF1 level is more difficult to explain. The data from the study suggest that optimal IGF1 levels are between 0 and +1 s.e.M. in adult patients.

In another large prospective Swedish study, serum IGF1 levels were measured in 2901 elderly men (mean age 75.4 years) and mortality data were obtained (mean follow-up 6 years) (43). This study confirmed a U-shaped association between serum IGF1 levels and mortality. Both low and high serum IGF1 levels were associated with increased cancer mortality, while low IGF1 levels were associated with increased cardiovascular disease mortality.

In summary, human population studies on the association of IGF1 concentrations and cancer have given variable results, possibly due to an extremely heterogeneous genetic background and poorly understood influence of environmental and behavioral factors.

\section{Hypopituitary patients with GHD not treated with GH}

Mortality is increased in patients with acquired hypopituitarism who are GH deficient $(11,44,45,46)$. Most studies are retrospective (without GH therapy), but some are prospective (with $\mathrm{GH}$ therapy). Most patients with GHD have multiple pituitary hormone deficiencies and have often undergone pituitary surgery and/or radiation. These patients require multiple hormone replacement and usually do not die prematurely from cancers but rather from cardiovascular and infectious diseases. In these patients, it remains unclear whether this increased cardiovascular mortality results from untreated GHD or from confounding factors (inadequate hormone replacement, surgery, radiation, etc.). The limitation of studies assessing mortality in patients with hypopituitarism is that the degree of hypopituitarism i.e. number of deficient axes and the number of patients tested specifically for GH deficiency is not clear in all studies. When these data are reported, the number of patients is quite low. Furthermore, hypopituitarism is a heterogeneous condition with different underlying etiologies. Caution should be exercised when reporting cancer incidences in many of these studies as they are often retrospective and as such may be inaccurate.

Regarding the incidence of malignancies in acquired hypopituitarism conflicting results have been reported. In some retrospective studies adult hypopituitary patients not treated with GH showed increased cancer risk $(11,45,46$, $47)$, while others did not $(48,49,50)$. A nationwide Swedish study included 1411 hypopituitary adults without GH replacement therapy and 289 hypopituitary adults on long-term GH replacement and compared both the populations with the normal population (11). In hypopituitary patients not treated with $\mathrm{GH}$, the overall mortality was increased compared with the normal population and the causes were myocardial infarction, cerebrovascular events and malignancies. The mean age of the patients in whom a malignancy was diagnosed was 64.7 years.

Regarding congenital hypopituitarism recent findings report prolonged life span in the 'little people of Krk' who survive to a very advanced age suggesting that when $\mathrm{GH} / \mathrm{IGF}$ secretion or action is inhibited humans live longer (51). However, life span in patients suffering from congenital isolated GHD (IGHD) due to GH1 gene deletion (causing complete absence of $\mathrm{GH}$ ) is reported to be shorter that the general population (males 56 years and females 46 years), with the main causes of death of these patients being heart and infectious diseases (52). Another large retrospective study measured longevity and compared mortality risk in 65 untreated patients with congenital IGHD (patients with a homozygous mutation in the GHRH receptor gene) with their 128 unaffected siblings from 34 families and the general population (53). These authors concluded that the risk of death of patients with congenital IGHD was not different from that of their siblings, and their life span was also not different from that of their siblings or the general population. A report of one confirmed cancer death in an individual with a homozygous mutation in the $G H R H$ receptor gene and one confirmed cancer death observed by us in a 42-year-old female with familial congenital hypopituitarism (not yet reported) shows that the protection against cancer by GHD is not absolute (53).

In summary, cancer risk in hypopituitary patients either of childhood-onset GHD or adult-onset (AO) GHD is complex and may be explained by factors other than hypopituitarism.

\section{Patients with congenital IGF1 deficiency}

When discussing the causes of death in 222 congenital IGF1-deficient individuals, no cancer cases were 
reported whereas a substantial percentage of family members had cancer, suggesting that the lack of IGF1 protects against cancer (54). In 90 Ecuadorian subjects with mutations in GHR leading to severe IGF1 deficiencies, only one nonlethal malignancy (a papillary serous epithelial tumor of the ovary) was reported in contrast to $17 \%$ cancer prevalence in the controls (55). Authors showed by in vitro studies that these GHRdeficient patients display a major reduction in pro-aging signaling. The sera from patients reduced DNA breaks, increased apoptosis in human mammary epithelial cells, and increased insulin sensitivity. These data from GHR-deficient patients are similar to those from GHRdeficient mice that display lower incidence (49\%) and delayed occurrence of fatal neoplasms and increased insulin sensitivity (21).

In summary, patients with congenital IGF1 deficiency have a protective effect against developing cancer.

\section{Hypopituitary patients with GHD replaced with GH}

Quantifying the risk of cancer in relation to $\mathrm{GH}$ therapy in GH-deficient patients is even more complex (56). Most data on the safety of GH replacement therapy in humans have been collected in observational and randomized controlled studies. These surveillance studies include all patients that received $\mathrm{GH}$ replacement therapy in conditions of routine clinical practice and their followup has been long term (57). There are many limitations and pitfalls concerning these observational studies. A significant proportion of the data is from large pharmaceutical-sponsored post-marketing surveillance studies. Although these registries reflect the real-life clinical practice, each study is under the control of its sponsor. The disadvantages are that: they rely on physicians reporting on adverse events and physician evaluation as to whether this is a GH-related event big centers are mostly reporting there are pitfalls in. Other pitfalls are in the methodology of IGF1 measurements, limited duration of follow up and the lack of control group. Nevertheless, the number of patients in these studies is large.

\section{Hypopituitary children with GHD replaced with GH}

The National Cooperative Growth Study (NCGS) analyzed 54996 children treated with recombinant human $\mathrm{GH}$ and confirmed a favorable overall safety profile with specific populations at potential risk (15). After more than 20 years, leukemia, a major safety issue initially believed to be associated with $\mathrm{GH}$, has not been confirmed. The authors reported no increase in new malignancies or recurrences of CNS tumors in GH-treated children without risk factors. The risk of second malignancies in patients previously treated with irradiation has been detected or confirmed through the NCGS (15). Second tumors were seen in 49 of the $\sim 2500$ patients enrolled in the NCGS who had a prior history of malignancy or $\sim 4.6$ cases per 1000 patient-years of $\mathrm{GH}$ exposure. The dominant risk factor appears to be a prior exposure to radiation. CNS tumors, followed by osteosarcoma, were the most frequently reported second neoplasms. The increased risk of developing second neoplasms in GH-treated childhood cancer survivors is now listed in US labeling for all rhGH products.

\section{Hypopituitary adults with GHD replaced with GH}

Patients with AO GHD have a decreased life expectancy due to increased mortality from cardiovascular diseases (44). In these patients important changes in cardiovascular risk factors (adverse lipid profile, increased BMI, and hypertension) are reported (58). Reports demonstrate that long-term GH replacement therapy in adults with GHD was not associated with an increase in mortality due to malignancies $(11,59,60)$. Importantly, GH replacement therapy was not associated with a higher overall SMR than previously reported (60). Two big observational studies (KIMS and Hypopituitary Control and Complications Study (HypoCCS)) analyzed in particular the incidence of cancer in adults treated with GH therapy. The practice among pediatric and adult endocrinologists is to titrate the $\mathrm{GH}$ dose to achieve serum IGF1 concentrations that are perceived as both efficacious and safe; 14752 patients received $\mathrm{GH}$ replacement and were enrolled in the Pfizer International Metabolic Database (KIMS) on March 16,2010 (61). The majority of these adult patients (58.2\%) had not received GH replacement before entry into KIMS. The mean follow-up time for all patients with an entry visit was 4.8 years. Malignant neoplasms have been reported as adverse events in 469 patients in KIMS (274 men and 195 women). The most frequently reported cancer types were skin cancers (including malignant melanoma), which were reported in 49 men and 38 women. The next most frequent cancer types were prostate cancer (77 men) and breast cancer (34 women). The interval between the start of GH therapy in KIMS and the diagnosis of a de novo neoplasm varied (range $<1-175$ months). A total of 41 patients were diagnosed with a malignant tumor within 6 months of enrolment in KIMS. In summary, this large database with long follow-up of GHD patients treated with GH or non-GH-treated patients showed no evidence of an increased risk of malignancy during GH replacement. In a sub-study from the same database on deaths among 1286 Swedish adult patients with hypopituitarism, allcause and cause-specific mortality were prospectively monitored (period 1995-2009) and compared with the general population data in the Swedish National Cause of Death Registry (62). In this sub-study an excess mortality was found due to hypocortisolism during 
acute stress and de novo malignant brain tumors. These malignant brain tumors were reported in eight patients (six of which had had a benign pituitary lesion as a primary disease). Six of these eight patients were previously treated with radiotherapy.

In another sub-study from the KIMS database on the association between IGF1, IGFBP2, and IGFBP3 in GHD adults receiving GH therapy and the occurrence of de novo malignancies, no association between IGF1 SDSs and relative risk (RR) of malignancy was found (63). However, increasing IGFBP2 and IGFBP3 SDSs were associated with increasing RRs of malignancy. The authors concluded that IGF1 levels targeted to within normal age-related reference ranges during $\mathrm{GH}$ replacement therapy are not associated with the occurrence of malignancies (63). Clinicians target IGF1 to -1.5 to +1.5 IGF1 SDS. Findings regarding IGFBP 2 and IGFBP 3 levels require additional confirmation. The overall cancer mortality rate in GH-deficient patients treated with GH in a recent KIMS study was not different from that in the general population (60).

Out of 7780 adult hypopituitary patients evaluated in the HypoCCS database (64), 6840 patients were treated with GH and 940 patients were not treated with $\mathrm{GH}$. The mean follow-up time was 3.7 years for GH-treated patients and 2.9 years for non-GH-treated patients. This prospective study reported 142 cancers in GH-treated patients, with an overall standardized incidence radio of 0.88 (95\% CI 0.74-1.04). The most common cancers in GH-treated patients were prostate cancer $(n=24)$, breast cancer $(n=16)$, malignant melanoma $(n=15)$, colorectal cancer $(n=11)$, lung cancer $(n=11)$, thyroid cancer $(n=9)$, and glioma $(n=9)$. These data showed that the incidence of primary cancers in patients with GHD enrolled in HypoCCS who were treated with GH as adults appears similar to that of the general population. A recent published prospective study compared adverse events in $1988 \mathrm{GHD}$ adults who were treated with GH with $443 \mathrm{GHD}$ patients who were not treated with $\mathrm{GH}$ in the United States (65). After a mean follow-up time of 2.3 years, the authors did not find any difference in rates of death, cancer, intracranial tumor growth, or recurrence, diabetes, or cardiovascular events in GH-treated compared with untreated patients. The limitation of this study is that the follow-up duration was quite short (3-4 years) to see an effect of a treatment on cancer incidence.

In summary, results from two large databases show that the incidence of primary cancers in adult patients with GHD who were treated with GH appears similar to the general population. It is reassuring that there is no association between IGF1 levels and cancer occurrence in adults with GHD treated with GH.

\section{GH excess (acromegaly) and the risk for neoplasms (too much GH/IGF1)}

Studies showed that overall mortality in acromegalic patients has increased $(66,67)$. Mortality is related to post-treatment $\mathrm{GH}$ levels in acromegalics; as disease control improves mortality decreases. Reduction of GH to $<1 \mu \mathrm{g} / \mathrm{l}$ or normalization of serum IGF1 reduces mortality to expected levels (66).

A recent comprehensive literature review of 12 years (1998-2010) confirmed that overall mortality in acromegaly has increased (67). Most deaths among acromegalic patients are attributable to cardiovascular and cerebrovascular diseases $(60 \%)$, followed by respiratory causes (25\%) (67). Cancer-related mortality in these patients did not increase. Cancer-related mortality in acromegaly varies widely amongst retrospective studies. In acromegaly, characterized by sustained elevation of GH and IGF1, some find increased cancer-related mortality while others do not. Orme et al. (68) reported a lower overall cancer incidence rate in 1362 acromegalics compared with the general population. Only the colon cancer mortality rate was higher than expected with a standardized mortality ratio (SMR) OR 2.47 (CI 1.31-4.22). Subsequent studies in acromegalic patients suggested that elevated levels of GH/IGF1 may be associated with an increased risk of malignant disease, in particular, colorectal cancer (68, 69, 70, 71). However, a large epidemiological study failed to show higher prevalence of colonic neoplasia in acromegaly (72). Recent findings in acromegalics who underwent colonoscopy show only $0.9 \%$ having colon cancer (73). Furthermore, newer studies show that colonic epithelial cell proliferation in acromegalics correlates with IGF1 but IGF1 does not induce neoplasia (74). An observational study of colorectal cancer in groups of patients with hereditary predisposition (familial adenomatous polyposis, hereditary nonpolyposis colorectal cancer) showed that the prevalence of colorectal cancer increases with age (75).

In a retrospective study we demonstrated an increased frequency of cancers not only in patients with acromegaly but also in patients with nonfunctional pituitary adenoma when compared with the general population, indicating that other factors besides GH/IGF1 might have a possible role in cancerogenesis (47). In summary, it has been proposed that both patients with pituitary adenomas and cancer may have underlying genetic and/or epigenetic instability.

\section{Risk for pituitary adenoma when cancer was diagnosed in the family}

Other factors besides GH/IGF1 may have a possible role in cancerogenesis $(11,47)$. It has been proposed that both pituitary adenomas and cancer may share a unifying nonendocrine (genetic and/or epigenetic) etiology $(76,77)$. Analysis of data from the Swedish Family-Cancer Database (with data on 10.5 million individuals and comprising families with parents and offspring) showed that there is a significant association of pituitary adenomas and some cancers in the family (77). 
The Swedish Family-Cancer Database from 1958 to 2002 included 3239 pituitary tumor patients. In this database pituitary adenomas are reported to have a low annual incidence $(n=100)$, while a total of 50000 cancers are reported annually in the general population. The results from this study suggest an association of pituitary adenomas with nervous system hemangiopericytoma, breast and colorectal cancers, in addition to some other tumor types (lymphatic leukemia, kidney cancer, skin cancer, and Hodgkin disease) among parents and offspring. Even more interesting are findings reported in a Dutch study on brain magnetic resonance imaging in long-term survivors of breast cancer, in whom contrary to the commonly held opinion that an increased prevalence of meningiomas would be found, increased prevalence of pituitary adenomas was found (78). In summary, both pituitary adenomas and cancer may share a unifying nonendocrine etiology.

\section{Modifiable cancer risk factors: obesity and insulin resistance}

As already mentioned, the potential influence of environmental and behavioral factors remains poorly understood. However, recent studies on modifiable cancer risk factors besides smoking describe obesity being responsible for cancer (eating our way to cancer diagnosis). Many hypopituitary patients are obese and insulin resistant (due to obesity and possibly supraphysiological glucocorticoid replacement). GH therapy increases insulin resistance. Obesity and insulin resistance are found to be associated with an increased incidence of solid tissue cancers (colorectal, endometrium, kidney, pancreas, esophagus, postmenopausal breast cancer, and gall bladder) (79). It has been estimated that $15-20 \%$ of all cancer deaths in the United States can be attributed to overweight or obesity (80). Those with a BMI $\geq 40$ had increased death rates from cancer ( $52 \%$ in men and $62 \%$ in women) compared with patients with normal weight. Epidemiological data suggest that obesity is associated with a 30-70\% increased risk of colon cancer in men, whereas this association is less consistent in women (81). Obesity might be associated with worse cancer outcomes, such as recurrence of the primary cancer or mortality. Visceral fat (abdominal obesity) is of greater concern than subcutaneous fat (82).

The underlying mechanisms linking obesity to cancer are still not well defined. Hyperinsulinemia, elevated IGF1 level, increased production of estrogens by adipose tissue (due to increased aromatase activity in adipose tissue), decrease of sex steroid-binding globulin (due to reduction in the hepatic synthesis by hyperinsulinemia), altered circulating levels of adipocytokines (TNF- $\alpha$, IL6, IL1, VEGF, leptin, heparin-binding epidermal growth factor-like growth factor (HB-EGF), adiponectin), inflammation and oxidative stress are possibly involved (79).
Recently it has been postulated that increased dietary intake of cholesterol is associated with increased risk of cancer in postmenopausal women. It has been shown that a cholesterol metabolite, 27-hydroxycholesterol, is a potential regulator of estrogen receptor signaling (endogenous selective estrogen receptor modulator) that may act as a partial estrogen agonist in breast cancer cells and influence the pathology of breast cancer (83).

In summary, it is not known whether obesity and insulin resistance found in hypopituitarism are modifiable risk factors for cancer.

\section{Conclusions}

There are important distinctions between experimental models and clinical studies in humans when quantifying the risk of cancer in relation to GH. GH therapy has a long track record of efficacy and safety in GH-deficient patients. The risk for developing a malignant disease in adult hypopituitary patients undergoing GH replacement should be studied with longer follow-up periods and in particular in the elderly. For survivors of childhood cancer, some data indicate that GH could induce a slight increase in the risk of developing a second neoplasm in patients with prior radiotherapy (radiotherapy is the main risk factor for secondary neoplasm in GH-treated patients). In general, the results up-to-date are encouraging concerning the risk of cancer occurrence in $\mathrm{GH}$ deficient patients treated with $\mathrm{GH}$.

\section{Declaration of interest}

V Popovic was on the advisory board of KIMS - Pfizer database and is currently a member of the International Board for Nordinet-Novo Nordisk.

\section{Funding}

This work was supported by a grant from the Ministry of Science of Republic of Serbia (Project 175033).

\section{References}

1 Moon HD, Simpson ME, Li CH \& Evans HM. Neoplasms in rats treated with pituitary growth hormone; pulmonary and lymphatic tissues. Cancer Research 195010 297-308.

2 Young S. Induction of mammary carcinoma in hypophysectomized rats treated with 3-methylcholanthrene, oestradiol-17 $\beta$, progesterone and growth hormone. Nature 1961190 356-357. (doi:10.1038/190356a0)

3 Harada Y. Pituitary role in the growth of metastasizing MRMT-1 mammary carcinoma in rats. Cancer Research 197636 18-22.

4 Rose DP \& Noonan JJ. Influence of prolactin and growth hormone on rat mammary tumors induced by $\mathrm{N}$-nitrosomethylurea. Cancer Research 198242 35-38.

5 Samani AA, Yakar S, LeRoith D \& Brodt P. The role of the IGF system in cancer growth and metastasis: overview and recent insights. Endocrine Reviews 200728 20-47. (doi:10.1210/ er.2006-0001) 
6 Seccareccia E \& Brodt P. The role of the insulin-like growth factor-I receptor in malignancy: an update. Growth Hormone $\mathcal{E}$ IGF Research 201222 193-199. (doi:10.1016/j.ghir.2012.09.003)

7 Renehan AG, Zwahlen M, Minder C, O'Dwyer ST, Shalet SM \& Egger M. Insulin-like growth factor (IGF)-I, IGF binding protein-3, and cancer risk: systematic review and meta-regression analysis. Lancet 2004363 1346-1353. (doi:10.1016/S0140-6736(04) 16044-3)

8 Pollak MN, Schernhammer ES \& Hankinson SE. Insulin-like growth factors and neoplasia. Nature Reviews. Cancer 20044 505-518. (doi:10.1038/nrc1387)

9 Swerdlow AJ, Higgins CD, Adlard P \& Preece MA. Risk of cancer in patients treated with human pituitary growth hormone in the UK. 1959-85: a cohort study. Lancet $2002 \quad 360$ 273-277. (doi:10.1016/S0140-6736(02)09519-3)

10 Monson JP. Long-term experience with GH replacement therapy: efficacy and safety. European Journal of Endocrinology $2003 \mathbf{1 4 8}$ (Suppl 2) S9-S14. (doi:10.1530/eje.0.148S009)

11 Svensson J, Bengtsson B-A, Rosen T, Oden A \& Johannsson G. Malignant disease and cardiovascular morbidity in hypopituitary adults with or without growth hormone replacement therapy. Journal of Clinical Endocrinology and Metabolism $2004 \mathbf{8 9}$ 3306-3312. (doi:10.1210/jc.2003-031601)

12 Abs R, Bengtsson B-A, Hernberg-Stahl E, Monson JP, Tauber JP, Wilton P \& Wüster C. GH replacement in 1034 growth hormone deficient hypopituitary adults: demographic and clinical characteristics, dosing and safety. Clinical Endocrinology $1999 \mathbf{5 0}$ 703-713. (doi:10.1046/j.1365-2265.1999.00695.x)

13 Murray RD, Darzy KH, Gleeson HK \& Shalet SM. GH-deficient survivors of childhood cancer: GH replacement during adult life. Journal of Clinical Endocrinology and Metabolism $2002 \mathbf{8 7}$ 129-135. (doi:10.1210/jc.87.1.129)

14 Wilton P, Mattsson AF \& Darendeliler F. Growth hormone treatment in children is not associated with an increase in the incidence of cancer: experience from KIGS (Pfizer International Growth Database). Journal of Pediatrics 2010157 265-270. (doi:10.1016/j.jpeds.2010.02.028)

15 Bell J, Parker KL, Swinford RD, Hoffman AR, Maneatis T \& Lippe B. Long-term safety of recombinant human growth hormone in children. Journal of Clinical Endocrinology and Metabolism 201095 167-177. (doi:10.1210/jc.2009-0178)

16 Sklar CA, Mertens AC, Mitby P, Occhiogrosso G, Qin J, Heller G, Yasui Y \& Robison LL. Risk of disease recurrence and second neoplasms in survivors of childhood cancer treated with growth hormone: a report from the childhood cancer survivor study. Journal of Clinical Endocrinology and Metabolism $2002 \mathbf{8 7}$ 3136-3141. (doi:10.1210/jc.87.7.3136)

17 Ergun-Longmire B, Mertens AC, Mitby P, Qin J, Heller G, Shi W, Yasui Y, Robison LL \& Sklar CA. Growth hormone treatment and risk of second neoplasms in the childhood cancer survivor. Journal of Clinical Endocrinology and Metabolism 200691 3494-3498. (doi:10.1210/jc.2006-0656)

18 Holly JMP \& Perks CM. Insulin-like growth factor physiology. Endocrinology and Metabolism Clinics of North America $2012 \mathbf{4 1}$ 249-263. (doi:10.1016/j.ecl.2012.04.009)

19 Maile LA \& Holly JM. Insulin-like growth factor binding protein (IGFBP) proteolysis: occurrence, identification, role and regulation. Growth Hormone \& IGF Research 19999 85-95. (doi:10.1054/ghir.1999.0096)

20 Bartke A \& Brown-Borg H. Life extension in the dwarf mouse. Current Topics in Developmental Biology 200463 189-225. (doi:10.1016/S0070-2153(04)63006-7)

21 Ikeno Y, Hubbard GB, Lee S, Cortez LA, Lew CM, Webb CR, Berryman DE, List EO, Kopchick JJ \& Bartke A. Reduced incidence and delayed occurrence of fatal neoplastic diseases in growth hormone receptor/binding protein knockout mice. Journals of Gerontology. Series A, Biological Sciences and Medical Sciences 2009 64 522-529. (doi:10.1093/gerona/glp017)

22 Yang XF, Bearmer WG, Huynh H \& Pollak M. Reduced growth of human breast cancer xenografts in hosts homozygous for the lit mutation. Cancer Research 199656 1509-1511.
23 Wu Y, Yakar S, Zhao L, Hennighausen L \& LeRoith D. Circulating insulin-like growth factor-I levels regulate colon cancer growth and metastasis. Cancer Research 200262 1030-1035.

$24 \mathrm{Wu}$ Y, Cui K, Miyoshi K, Hennighausen L, Green JE, Setser J, LeRoith D \& Yakar S. Reduced circulating insulin-like growth factor I levels delay the onset of chemically and genetically induced mammary tumors. Cancer Research 200363 4384-4388.

25 Ohneda K, Ulshen MH, Fuller CR, D'Ercole AJ \& Lund PK. Enhanced growth of small bowel in transgenic mice expressing human insulin-like growth factor I. Gastroenterology 1997112 444-454. (doi:10.1053/gast.1997.v112.pm9024298)

26 Freier S, Weiss O, Eran M, Flyvbjerg A, Dahan R, Nephesh I, Safra T, Shiloni E \& Raz I. Expression of the insulin-like growth factors and their receptors in adenocarcinoma of the colon. Gut 199944 704-708. (doi:10.1136/gut.44.5.704)

27 Khandwala H, McCutcheon I, Flyvberg A \& Friend K. The effects of insulin-like growth factors on tumorigenesis and neoplastic growth. Endocrine Reviews 200021 215-244. (doi:10.1210/ er.21.3.215)

28 Holly J \& Perks C. Growth hormone and cancer: are we asking the right questions? Clinical Endocrinology $2006 \quad 64$ 122-124. (doi:10.1111/j.1365-2265.2006.02409.x)

29 Peyrat JP, Bonneterre J, Hecquet B, Vennin P, Louchez MM, Fournier C, Lefebvre J \& Demaille A. Plasma insulin-like growth factor-I (IGF-I) concentrations in human breast cancer. European Journal of Cancer 1993 29A 492-497. (doi:10.1016/ S0959-8049(05)80137-6)

30 Chan JM, Stampfer MJ, Giovannucci E, Gann PH, Ma J, Wilkinson P, Hennekens CH \& Pollak M. Plasma insulin-like growth factor-I and prostate cancer risk: a prospective study. Science $1998 \mathbf{2 7 9}$ 563-566. (doi:10.1126/science.279.5350.563)

31 Hankinson S, Willett W, Colditz G, Hunter DJ, Michaud DS, Deroo B, Rosner B, Speizer FE \& Pollak M. Circulating concentrations of insulin-like growth factor-I and risk of breast cancer. Lancet $1998 \quad 351 \quad 1393-1396 . \quad$ (doi:10.1016/ S0140-6736(97)10384-1)

32 Ma J, Pollak M, Giovannucci E, Chan JM, Tao Y \& Hennekens CH. Prospective study of colorectal cancer risk in men and plasma levels of insulin-like growth factor (IGF)-I and IGF-binding protein-3. Journal of the National Cancer Institute $1999 \mathbf{9 1}$ 620-625. (doi:10.1093/jnci/91.7.620)

33 Giovannucci E, Pollak MN, Platz EA, Willett WC, Stampfer MJ, Majeed N, Colditz GA, Speizer FE \& Hankinson SE. A prospective study of plasma insulin-like growth factor-I and binding protein-3 and risk of colorectal neoplasia in women. Cancer Epidemiology, Biomarkers \& Prevention 20009 345-349.

34 Chan J. Stampfer M, Giovannucci E, Ma J \& Pollak M. Insulin-like growth factor I (IGF-I), IGF binding protein-3 and prostate cancer risk: epidemiological studies. Growth Hormone \& IGF Research 2000 10 (Suppl A) S32-S33. (doi:10.1016/S1096-6374(00)90015-7)

35 Shaneyfelt T, Husein R, Bubley G \& Mantzoros C. Hormonal predictors of prostate cancer: a meta-analysis. Journal of Clinical Oncology 200018 847-853.

36 Rowlands MA, Holly JM, Gunnell D, Donovan J, Lane JA, Hamdy F, Neal DE, Oliver S, Smith GD \& Martin RM. Circulating insulin-like growth factors and IGF-binding proteins in PSA-detected prostate cancer: the large case-control study ProtecT. Cancer Research 201272 503-515. (doi:10.1158/0008-5472.CAN-11-1601)

37 Stattin P, Bylund A, Rinaldi S, Biessy C, Déchaud H, Stenman UH, Egevad L, Riboli E, Hallmans G \& Kaaks R. Plasma insulin-like growth factor-I, insulin-like growth factor-binding proteins, and prostate cancer risk: a prospective study. Journal of the National Cancer Institute 200092 1910-1917. (doi:10.1093/jnci/92.23.1910)

38 Chokkalingam AP, Pollak M, Fillmore CM, Gao YT, Stanczyk FZ, Deng J, Sesterhenn IA, Mostofi FK, Fears TR, Madigan MP et al. Insulin-like growth factors and prostate cancer: a populationbased case-control study in China. Cancer Epidemiology, Biomarkers \& Prevention $200110421-427$.

39 Pazaitou-Panayiotou K, Kelesidis T, Kelesidis I, Kaprara A, Blakeman J, Vainas I, Mpousoulegas A, Williams CJ \& Mantzoros C. Growth hormone-binding protein is directly and 
IGFBP-3 is inversely associated with risk of female breast cancer. European Journal of Endocrinology $2007 \quad \mathbf{1 5 6} \quad 187-194$. (doi:10.1530/EJE-06-0611)

40 Baglietto L, English DR, Hopper JL, Morris HA, Tilley WD \& Giles GG. Circulating insulin-like growth factor-I and binding protein-3 and the risk of breast cancer. Cancer Epidemiology, Biomarkers \& Prevention $2007 \quad 16$ 763-768. (doi:10.1158/ 1055-9965.EPI-06-0960)

41 Rinaldi S, Cleveland R, Norat T, Biessy C, Rohrmann S, Linseisen J, Boeing H, Pischon T, Panico S, Agnoli C et al. Serum levels of IGF-I, IGFBP-3 and colorectal cancer risk: results from the EPIC cohort, plus a meta-analysis of prospective studies. International Journal of Cancer 2010126 1702-1715. (doi:10.1002/ijc.24927)

42 Burgers AM, Biermasz NR, Schoones JW, Pereira AM, Renehan AG, Zwahlen M, Egger M \& Dekkers OM. Meta-analysis and dose-response metaregression: circulating insulin-like growth factor I (IGF-I) and mortality. Journal of Clinical Endocrinology and Metabolism 201196 2912-2920. (doi:10.1210/jc.2011-1377)

43 Svensson J, Carlzon D, Petzold M, Karlsson MK, Ljunggren O, Tivesten A, Mellstrom D \& Ohlsson C. Both low and high serum IGF-I levels associate with cancer mortality in older men. Journal of Clinical Endocrinology and Metabolism 201297 4623-4630. (doi:10.1210/jc.2012-2329)

44 Rosen T \& Bengtsson B-A. Premature mortality due to cardiovascular diseases in hypopituitarism. Lancet 1990336 285-288. (doi:10.1016/0140-6736(90)91812-0)

45 Stochholm K, Gravholt C. Laursen T, Laurberg P, Andersen M, Kristensen LØ, Feldt-Rasmussen U, Christiansen JS, Frydenberg M \& Green A. Mortality and GH deficiency: a nationwide study. European Journal of Endocrinology 2007 157 9-18. (doi:10.1530/ EJE-07-0013)

46 Bates A, Van't Hoff W, Jones P \& Clayton R. The effect of hypopituitarism on life expectancy. Journal of Clinical Endocrinology and Metabolism 199681 1169-1172. (doi:10.1210/jc.81.3.1169)

47 Popovic V, Damjanovic S, Micic D, Nesovic M, Djurovic M, Petakov M, Obradovic S, Zoric S, Simic M, Penezic Z et al. Increased incidence of neoplasia in patients with pituitary adenoma. The Pituitary Study Group. Clinical Endocrinology 199849 441-445. (doi:10.1046/j.1365-2265.1998.00536.x)

48 Tomlinson J, Holden N, Hills R, Wheatley K, Clayton RN, Bates AS, Sheppard MC \& Stewart PM. Association between premature mortality and hypopituitarism. West Midlands Prospective Hypopituitary Study Group. Lancet 2001357 425-431. (doi:10.1016/ S0140-6736(00)04006-X)

49 Erfurth EM, Bullow B, Mikoczy Z \& Hagmar L. Incidence of a second tumor in hypopituitary patients operated for pituitary tumors. Journal of Clinical Endocrinology and Metabolism 200186 659-662. (doi:10.1210/jc.86.2.659)

50 Bulow B, Hagmar L, Mikoczy Z, Nordstrom CH \& Erfurth EM. Increased cerebrovascular mortality in patients with hypopituitarism. Clinical Endocrinology $1997 \quad 46 \quad 75-81$. (doi:10.1046/ j.1365-2265.1997.d01-1749.x)

51 Krzisnik C, Grguric S, Cvijovic K \& Laron Z. Longevity of the hypopituitary patients from the island Krk: a follow-up study. Pediatric Endocrinology Reviews 20107 357-362.

52 Besson A, Salemi S, Gallati S, Jenal A, Horn R, Mullis PS \& Mullis PE. Reduced longevity in untreated patients with isolated growth hormone deficiency. Journal of Clinical Endocrinology and Metabolism 200388 3664-3667. (doi:10.1210/jc.2002-021938)

53 Aguiar-Oliveira MH, Oliveira FT, Pereira RM, Oliveira CR, Blackford A, Valenca EH, Santos EG, Gois-Junior MB, MeneguzMoreno RA, Araujo VP et al. Longevity in untreated congenital growth hormone deficiency due to a homozygous mutation in the GHRH receptor gene. Journal of Clinical Endocrinology and Metabolism 201095 714-721. (doi:10.1210/jc.2009-1879)

54 Shevah O \& Laron Z. Patients with congenital deficiency of IGF-I seem protected from the development of malignancies: a preliminary report. Growth Hormone \& IGF Research $2007 \mathbf{1 7}$ 54-57. (doi:10.1016/j.ghir.2006.10.007)

55 Guevara-Aguirre J, Balasubramanian P, Guevara-Aguirre M, Wei M, Madia F, Cheng CW, Hwang D, Martin-Montalvo A,
Saavedra J, Ingles S et al. Growth hormone receptor deficiency is associated with a major reduction in pro-aging signaling, cancer, and diabetes in humans. Science Translational Medicine 20113 70ra13. (doi:10.1126/scitranslmed.3001845)

56 Rosenfeld RG, Cohen P, Robison LL, Bercu BB, Clayton P, Hoffman AR, Radovick S, Saenger P, Savage MO \& Wit JM. Long-term surveillance of growth hormone therapy. Journal of Clinical Endocrinology and Metabolism $2012 \quad 97 \quad 68-72$. (doi:10.1210/jc.2011-2294)

57 Gutiérrez LP, Koltowska-Häggström M, Jönsson PJ, Mattsson AF, Svensson D, Westberg B \& Luger A. Registries as a tool in evidencebased medicine: example of KIMS (Pfizer International Metabolic Database). Pharmacoepidemiology and Drug Safety $2008 \mathbf{1 7}$ 90-102. (doi:10.1002/pds.1510)

58 de Boer H, Blok GJ \& Van der Veen EA. Clinical aspects of growth hormone deficiency in adults. Endocrine Reviews 199516 63-86. (doi:10.1210/er.16.1.63)

59 van Bunderen CC, van Nieuwpoort IC, Arwert LI, Heymans MW, Franken AA, Koppeschaar HP, van der Lely AJ \& Drent ML. Does growth hormone replacement therapy reduce mortality in adults with growth hormone deficiency? Data from the Dutch National Registry of Growth Hormone Treatment in adults. Journal of Clinical Endocrinology and Metabolism 201196 3151-3159. (doi:10.1210/jc.2011-1215)

60 Gaillard RC, Mattsson AF, Akerblad AC, Bengtsson BÅ, Cara J, Feldt-Rasmussen U, Koltowska-Häggström M, Monson JP, Saller B, Wilton P et al. Overall and cause-specific mortality in GH-deficient adults on GH replacement. European Journal of Endocrinology 2012 166 1069-1077. (doi:10.1530/EJE-11-1028)

61 KIMS (Pfizer International Metabolic Database). "Safety,". In Overview, vol 13, pp 27-30. Eds P Touraine \& M KoltowskaHaggstrom, 2010.

62 Burman P, Mattsson AF, Johannsson G, Hoybye C, Holmer H, Dahlqvist P, Berinder K, Engstrom BE, Ekman D, Erfurth EM et al. Deaths among adult patients with hypopituitarism: hypocortisolism during acute stress, and de novo malignant brain tumors contribute to an increased mortality. Journal of Clinical Endocrinology and Metabolism 201398 1466-1475. (doi:10.1210/jc.2012-4059)

63 Popovic V, Mattsson AF, Gaillard RC, Wilton P, KoltowskaHaggstrom M \& Ranke MB. Serum insulin-like growth factor I (IGF-I), IGF-binding proteins 2 and 3, and the risk for development of malignancies in adults with growth hormone (GH) deficiency treated with GH: data from KIMS (Pfizer International Metabolic Database). Journal of Clinical Endocrinology and Metabolism 2010 95 4449-4454. (doi:10.1210/jc.2010-0287)

64 Child CJ, Zimmermann AG, Woodmansee WW, Green DM, Li JJ, Jung H, Erfurth EM, Robison LL \& HypoCCS International Advisory Board. Assessment of primary cancers in GH-treated adult hypopituitary patients: an analysis from the Hypopituitary Control and Complications Study. European Journal of Endocrinology 2011165 217-223. (doi:10.1530/EJE-11-0286)

65 Hartman ML, Xu R, Crowe BJ, Robison LL, Erfurth EM, Kleinberg DL, Zimmermann AG, Woodmansee WW, Cutler GB Jr, Chipman JJ et al. Prospective safety surveillance of $\mathrm{GH}$-deficient adults: comparison of $\mathrm{GH}$-treated vs untreated patients. Journal of Clinical Endocrinology and Metabolism $2013 \quad 98$ 980-988. (doi:10.1210/jc.2012-2684)

66 Holdaway IM, Rajasoorya RC \& Gamble GD. Factors influencing mortality in acromegaly. Journal of Clinical Endocrinology and Metabolism 200489 667-674. (doi:10.1210/jc.2003-031199)

67 Ben-Shlomo A, Sheppard MC, Stephens JM, Pulgar S \& Melmed S. Clinical, quality of life, and economic value of acromegaly disease control. Pituitary 201114 284-294. (doi:10.1007/s11102-0110310-7)

68 Orme SM, McNally RJ, Cartwright RA \& Belchetz PE. Mortality and cancer incidence in acromegaly: a retrospective cohort study. United Kingdom Acromegaly Study Group. Journal of Clinical Endocrinology and Metabolism $1998 \quad \mathbf{8 3} \quad 2730-2734$. (doi:10.1210/jc.83.8.2730)

69 Bengtsson B-A. Acromegaly and neoplasia. Journal of Pediatric Endocrinology 19936 73-78. (doi:10.1515/JPEM.1993.6.1.73) 
70 Jenkins P \& Besser M. Clinical perspective: acromegaly and cancer: a problem. Journal of Clinical Endocrinology and Metabolism 2001 86 2935-2941. (doi:10.1210/jc.86.7.2935)

71 Renehan AG, Odwyer ST \& Shalet SM. Screening colonoscopy for acromegaly in perspective. Clinical Endocrinology 200155 731-733. (doi:10.1046/j.1365-2265.2001.01355.x)

72 Bhansali A, Kochhar R, Chawla YK, Reddy S \& Dash RJ. Prevalence of colonic polyps is not increased in patients with acromegaly: analysis of 60 patients from India. Journal of Gastroenterology and Hepatology 200419 266-269. (doi:10. 1111/j.1440-1746.2003.03282.x)

73 Gullu BE, Celik O, Gazioglu N \& Kadioglu P. Thyroid cancer is the most common cancer associated with acromegaly. Pituitary 2010 13 242-248. (doi:10.1007/s11102-010-0224-9)

74 Dutta P, Bhansali A, Vaiphei K, Dutta U, Ravi Kumar P, Masoodi S, Mukherjee KK, Varma A \& Kochhar R. Colonic neoplasia in acromegaly: increased proliferation or deceased apoptosis? Pituitary 201215 166-173. (doi:10.1007/s11102-011-0300-9)

75 Renehan AG, O'Connell J, O'Halloran D, Shanahan F, Potten CS, O'Dwyer ST \& Shalet SM. Acromegaly and colorectal cancer: a comprehensive review of epidemiology, biological mechanisms, and clinical implications. Hormone and Metabolic Research 200335 712-725. (doi:10.1055/s-2004-814150)

76 Loeper S \& Ezzat S. Acromegaly: re-thinking the cancer risk. Reviews in Endocrine and Metabolic Disorders 2008 9 41-58. (doi:10.1007/s11154-007-9063-z)

77 Hemminki K, Försti A \& Ji J. Incidence and familial risks in pituitary adenoma and associated tumors. Endocrine-Related Cancer 200714 103-109. (doi:10.1677/ERC-06-0008)
78 Koppelman V, Schagen SB, Poels MM, Boogerd W, Seynaeve C, van der Luqt A \& Breteler MM. Incidental findings on brain magnetic resonance imaging in long-term survivors of breast cancer treated with adjuvant chemotherapy. European Journal of Cancer 201147 2531-2536. (doi:10.1016/j.ejca.2011.06.026)

79 Forte V, Pandey A, Abdelmessih R, Forte G, Whaley-Connell A, Sowers JR \& McFarlane SI. Obesity, diabetes, the cardiorenal syndrome, and risk for cancer. Cardiorenal Medicine 20122 143-162. (doi:10.1159/000337314)

80 Calle EE, Rodriguez C, Walker-Thurmond K \& Thun MJ. Overweight, obesity, and mortality from cancer in a prospectively studied cohort of U.S. adults. New England Journal of Medicine 2003 348 1625-1638. (doi:10.1056/NEJMoa021423)

81 Bardou M, Barkun AN \& Martel M. Obesity and colorectal cancer. Gut 2013 62 933-947. (doi:10.1136/gutjnl-2013-304701)

82 Garg SK, Maurer H, Reed K \& Selaqamsetty R. Diabetes and cancer: two diseases with obesity as a common risk factor. Diabetes, Obesity $\mathcal{E}$ Metabolism 2013. In press. (doi:10.1111/ dom.12124)

83 DuSell CD \& McDonnell DP. 27-Hydroxycholesterol: a potential endogenous regulator of estrogen receptor signaling. Trends in Pharmacological Sciences 200829 510-514. (doi:10.1016/ j.tips.2008.07.003)

Received 8 May 2013

Revised version received 17 July 2013

Accepted 9 August 2013 